\title{
Erectile Dysfunction and Undiagnosed Diabetes, Hypertension, and Hypercholesterolemia
}

Sean C. Skeldon, $M D^{1-3}$

Allan S. Detsky, MD, $P b D^{4}$

S. Larry Goldenberg, $M D^{3}$

Michael R. Law, $P b D^{1}$

'The Centre for Health Services and Policy Research, School of Population and Public Health, The University of British Columbia, Vancouver, British Columbia, Canada

${ }^{2}$ Department of Family and Community Medicine, University of Toronto, Toronto, Ontario, Canada

${ }^{3}$ Department of Urological Sciences, The University of British Columbia, Vancouver, British Columbia, Canada

${ }^{4}$ The Institute of Health Policy, Management and Evaluation, and Department of Medicine, University of Toronto, and the Department of Medicine, Mount Sinai Hospital and University Health Network, Toronto, Ontario, Canada

Conflicts of interest: authors report none.

\section{CORRESPONDING AUTHOR}

Sean C. Skeldon, MD

UBC Centre for Health Services and Policy

Research

201 - 2206 East Mall

Vancouver BC, V6T 1Z3

sean.skeldon@ubc.ca

\begin{abstract}
PURPOSE We investigated whether erectile dysfunction, a marker for future cardiovascular disease, is associated with undiagnosed cardiometabolic risk factors among US men. Identifying the presence of these risk factors could lead to earlier initiation of treatment for primary prevention of cardiovascular disease.
\end{abstract}

METHODS We analyzed cross-sectional data from men aged 20 years and older who participated in the National Health and Nutrition Examination Survey during 2001-2004. Erectile dysfunction was determined by a single, validated survey question. We used logistic regression analyses to investigate the relationship between erectile dysfunction and undiagnosed hypertension, hypercholesterolemia, and diabetes.

RESULTS After multivariate adjustment, men with erectile dysfunction had more than double the odds of having undiagnosed diabetes (odds ratio $=2.20$; $95 \% \mathrm{Cl}, 1.10-4.37)$, whereas no association was seen for undiagnosed hypertension or undiagnosed hypercholesterolemia. For the average man aged 40 to 59 years, the predicted probability of having undiagnosed diabetes increased from 1 in 50 in the absence of erectile dysfunction to 1 in 10 in the presence of erectile dysfunction.

CONCLUSIONS Our results underscore the importance of erectile dysfunction as a marker of undiagnosed diabetes. Erectile dysfunction should be a trigger to initiate diabetes screening, particularly among middle-aged men.

Ann Fam Med 2015;13:331-335. doi: 10.1370/afm.1816.

\section{INTRODUCTION}

$\mathrm{O}$ ne of every 3 deaths in the United States is attributable to cardiovascular disease (CVD). ${ }^{1}$ With $45 \%$ of US adults having hypertension, hypercholesterolemia, or diabetes, early diagnosis and effective management of these cardiometabolic risk factors can markedly reduce the impact of CVD. ${ }^{2}$ Unfortunately, in more than $15 \%$ of US adults, 1 or more of these 3 cardiometabolic risk factors is undiagnosed. ${ }^{2}$ From a public health perspective, underdiagnosis is concerning as it limits the potential benefits of early recognition and risk reduction. This is particularly true for men, owing to their greater reluctance to use preventive care and significantly higher prevalence of CVD compared with women. ${ }^{3,4}$ Identifying easily observable risk factors associated with undiagnosed cardiometabolic risk factors, particularly in men, may improve early diagnosis and subsequent treatment.

Over the past decade, evidence has suggested that erectile dysfunction is an early indicator for cardiovascular disease. ${ }^{5}$ In light of this association, erectile dysfunction has been described as providing a "window of curability" for men at risk for future CVD. There is a lack of empirical evidence on whether erectile dysfunction is a risk factor for having underlying cardiometabolic risk factors, however. We studied the association between erectile dysfunction and undiagnosed hypertension, hypercholesterolemia, and diabetes mellitus in a nationally representative sample of men. 


\section{METHODS}

\section{Data Source}

We analyzed data from the National Health and Nutrition Examination Survey (NHANES), a nationally representative survey of the resident civilian, noninstitutionalized US population conducted in 2-year cycles that has previously been described. ${ }^{6}$ We pooled the 2001-2002 and 2003-2004 cycles of NHANES, as these survey waves were the most recent that asked questions regarding erectile dysfunction.

\section{Measures}

Erectile dysfunction was assessed in NHANES with the question: "Many men experience problems with sexual intercourse. How would you describe your ability to get and keep an erection adequate for satisfactory intercourse?" This single, self-reported question has previously been validated for clinical erectile dysfunction. ${ }^{7}$ Using an approach similar to that used in previous studies, ${ }^{8}$ we considered men who responded "never able" or "sometimes able" to have erectile dysfunction and considered those who responded "usually able" or "always or almost always able" to have normal erectile function.

We likewise determined the presence of previously diagnosed cardiometabolic risk factors using an approach similar to that used in prior studies. ${ }^{9}$ For each risk factor, men were classified as already having the diagnosis if they responded that they had been told by a doctor or health professional that they had the condition or if they reported taking medications for it. In our statistical models, we also included potential confounding variables based on those used in earlier studies. ${ }^{8}$ Our study used physical examination and laboratory measures to identify undiagnosed cardiometabolic risk factors, using the same diagnostic criteria as used by the National Center for Health Statistics. ${ }^{2}$

From the 21,161 respondents to NHANES for 2001-2004, we studied the 4,519 men aged 20 years or older who had completed both the interview and physical examination components. Men with prostate cancer or missing responses to the question on erectile function or the other covariates were excluded (Supplemental Figure, available at http://www.annfammed. org/content/13/4/331/suppl/DC1). Three study analytic subsamples were created, as described below.

\section{Statistical Analysis}

We used logistic regression analysis to investigate the relationships of erectile dysfunction with undiagnosed hypertension, undiagnosed hypercholesterolemia, and undiagnosed diabetes in each of the corresponding analytic samples: men having a blood pressure measurement, a cholesterol measurement, and a fast- ing glucose measurement, respectively. Adjusted odds ratios (ORs) and their 95\% CIs were then estimated using multivariate logistic regression analysis as described in the NHANES analytic guidelines. ${ }^{10} \mathrm{We}$ performed an additional post hoc analysis to test for interactions between erectile dysfunction and age. The predicted probability of each outcome in the average man was then determined using the regression coefficients from each model. Because of missing data, we adjusted the original sampling weights for nonresponse as described by Lohr ${ }^{11}$ and recommended in the NHANES analy tic guidelines. ${ }^{10}$ We used SAS version 9.3 (SAS Institute) for all analyses.

\section{RESULTS}

We assessed the association of erectile dysfunction with undiagnosed hypertension among 2,224 men with a blood pressure reading; with undiagnosed hypercholesterolemia among 2,287 men with a cholesterol sample, and with undiagnosed diabetes among 1,417 men with a fasting glucose measurement. Characteristics of these analytic samples are shown in Table 1.

In the blood pressure analytic sample, 19.4\% of men with erectile dysfunction had undiagnosed hypertension compared with $9.3 \%$ of men without erectile dysfunction. Before statistical adjustment, the odds of having undiagnosed hypertension were higher among men with erectile dysfunction $(\mathrm{OR}=2.35$; 95\% CI, 1.78-3.11) compared to those without erectile dysfunction (Table 2). After we adjusted for potential confounders, however, the association was attenuated and was no longer statistically significant $(\mathrm{OR}=1.27$; 95\% CI, 0.87-1.85).

In the cholesterol analytic sample, we found no statistically significant association between erectile dysfunction and undiagnosed hypercholesterolemia in either the unadjusted or adjusted analysis (Table 2).

In the fasting glucose analytic sample, we found the prevalence of undiagnosed diabetes was $11.5 \%$ in men with erectile dysfunction compared with $2.8 \%$ in men without erectile dysfunction. The difference was most pronounced in middle-aged men (those 40 to 59 years old), in whom the prevalence of undiagnosed diabetes was $19.1 \%$ among men with erectile dysfunction compared with 3.3\% among men without the condition. We found that erectile dysfunction was strongly associated with undiagnosed diabetes in both the unadjusted analysis $(\mathrm{OR}=4.58 ; 95 \% \mathrm{CI}, 2.54-8.24)$ and the adjusted analysis $(\mathrm{OR}=2.20 ; 95 \% \mathrm{CI}, 1.10-4.37)$ (Table 2).

Our post hoc analysis found a significant interaction between erectile dysfunction and age in the fasting glucose sample $(P<.001)$, but not in the blood pressure or cholesterol samples. In short, this interac- 
Table 1. Characteristics of Analytic Study Samples

\begin{tabular}{|c|c|c|c|}
\hline Characteristic & $\begin{array}{c}\text { Blood Pressure } \\
\text { Sample, No. (\%) } \\
(n=2,224)\end{array}$ & $\begin{array}{c}\text { Cholesterol Sample, } \\
\text { No. }(\%) \\
(n=2,287)\end{array}$ & $\begin{array}{l}\text { Fasting Glucose } \\
\text { Sample, No. (\%) } \\
\qquad(n=1,417)\end{array}$ \\
\hline \multicolumn{4}{|l|}{ Erectile dysfunction } \\
\hline No & $1,874(89.1)$ & $1,813(87.3)$ & $1,090(83.8)$ \\
\hline Yes & $350(10.9)$ & $474(12.7)$ & $327(16.2)$ \\
\hline \multicolumn{4}{|l|}{ Age-group, y } \\
\hline $20-39$ & $1,029(49.8)$ & $1,027(51.5)$ & $539(43.6)$ \\
\hline $40-59$ & $789(40.3)$ & $732(37.1)$ & $487(40.5)$ \\
\hline$\geq 60$ & $350(9.9)$ & $528(11.5)$ & $391(15.9)$ \\
\hline \multicolumn{4}{|l|}{ Ethnicity } \\
\hline White & $1,142(71.4)$ & $1,158(70.4)$ & $788(72.6)$ \\
\hline Black & $391(9.1)$ & $441(10.2)$ & $242(9.8)$ \\
\hline Mexican American & $539(10.2)$ & $542(10.1)$ & $297(8.5)$ \\
\hline Other & $152(9.3)$ & $146(9.3)$ & $90(9.1)$ \\
\hline \multicolumn{4}{|l|}{ Physically active ${ }^{a}$} \\
\hline No & $1,267(58.1)$ & $1,329(59.4)$ & $834(61.2)$ \\
\hline Yes & $957(41.9)$ & $958(40.6)$ & $583(38.8)$ \\
\hline \multicolumn{4}{|l|}{ Alcohol use } \\
\hline Never & $159(7.1)$ & $164(7.3)$ & $97(6.8)$ \\
\hline Former & $195(8.2)$ & $209(8.8)$ & $130(9.1)$ \\
\hline Current & $1,870(84.6)$ & $1,914(83.8)$ & $1,190(84.1)$ \\
\hline \multicolumn{4}{|l|}{ Current smoker } \\
\hline No & $1,559(69.8)$ & $1,596(68.6)$ & $1,043(72.5)$ \\
\hline Yes & $665(30.2)$ & $691(31.4)$ & $374(27.5)$ \\
\hline \multicolumn{4}{|l|}{ History of hypertension } \\
\hline No & $2,224(100.0)$ & $1,799(82.4)$ & $1,042(75.6)$ \\
\hline Yes & $0(0.0)$ & $488(17.6)$ & $375(24.4)$ \\
\hline \multicolumn{4}{|l|}{ History of high cholesterol } \\
\hline No & $1,779(79.5)$ & $2,287(100.0)$ & $1,025(72.2)$ \\
\hline Yes & $445(20.5)$ & $0(0.0)$ & $392(27.8)$ \\
\hline \multicolumn{4}{|l|}{ History of diabetes } \\
\hline No & $2,130(96.9)$ & $2,159(96.8)$ & $1,417(100.0)$ \\
\hline Yes & $94(3.1)$ & $128(3.2)$ & $0(0.0)$ \\
\hline \multicolumn{4}{|l|}{ History of cardiovascular disease $\mathrm{e}^{b}$} \\
\hline No & $2,154(97.7)$ & $2,160(96.8)$ & $1,282(93.4)$ \\
\hline Yes & $70(2.3)$ & $127(3.2)$ & $135(6.6)$ \\
\hline \multicolumn{4}{|c|}{ Family history of hypertension/stroke } \\
\hline No & $1,668(72.8)$ & $1,669(70.5)$ & $1,028(69.6)$ \\
\hline Yes & $556(27.2)$ & $618(29.5)$ & $389(30.4)$ \\
\hline \multicolumn{4}{|c|}{ Family history of angina/heart attack ${ }^{c}$} \\
\hline No & $1,985(87.0)$ & $2,043(87.0)$ & $1,263(86.6)$ \\
\hline Yes & $239(13.0)$ & $244(13.0)$ & $154(13.4)$ \\
\hline \multicolumn{4}{|l|}{ Family history of diabetes } \\
\hline No & $1,217(54.3)$ & $1,262(55.3)$ & $779(54.8)$ \\
\hline Yes & $1,007(45.7)$ & $1,025(44.7)$ & $638(45.2)$ \\
\hline \multicolumn{4}{|l|}{ Weight status $^{d}$} \\
\hline Normal weight/underweight & $681(30.8)$ & $689(30.8)$ & $364(25.4)$ \\
\hline Overweight & $760(33.6)$ & $727(31.3)$ & $476(33.2)$ \\
\hline Obese & $783(35.7)$ & $871(37.9)$ & $577(41.5)$ \\
\hline \multicolumn{4}{|l|}{ Undiagnosed disease } \\
\hline No & $1,933(89.3)$ & $2,017(87.9)$ & $1,352(95.8)$ \\
\hline Yes $^{\mathrm{e}}$ & $291(10.4)$ & $270(12.1)$ & $65(4.2)$ \\
\hline
\end{tabular}

Note: All percentages are probability weighted to account for the National Health and Nutrition Examination Survey sampling design.

a Men responding "more active" to the question "Compared with most men your age, would you say that you are ..." were considered to be physically active; those responding "less active" or "about the same" were considered not physically active.

b Included angina, heart attack, coronary heart disease, congestive heart failure, or stroke.

' Before the age of 50 .

d Using World Health Organization classification: obese (body mass index [BMI] $\geq 30 \mathrm{~kg} / \mathrm{m}^{2}$ or waist circumference [WC] $\geq 102 \mathrm{~cm}$ ), overweight (BMI $\geq 25 \mathrm{~kg} / \mathrm{m}^{2}$ but $<30 \mathrm{~kg} / \mathrm{m}^{2}$ or WC $\geq 94 \mathrm{~cm}$ but $<102 \mathrm{~cm}$ ), or normal weight or underweight (BMl $<25 \mathrm{~kg} / \mathrm{m}^{2}$ or WC $<94 \mathrm{~cm}$ ).

e Undiagnosed hypertension: average systolic blood pressure $\geq 140 \mathrm{~mm} \mathrm{Hg}$ or diastolic blood pressure $\geq 90 \mathrm{~mm} \mathrm{Hg}$; undiagnosed hypercholesterolemia: total cholesterol $\geq 6.21 \mathrm{mmol} / \mathrm{L}$ ( $\geq 240 \mathrm{mg} / \mathrm{dL}$ ); undiagnosed diabetes: fasting plasma glucose level $\geq 126 \mathrm{mg} / \mathrm{dL}$ ( $\geq 7.0 \mathrm{mmol} / \mathrm{L})$. 
Table 2. Odds Ratios (95\% Cls) for Association of Erectile Dysfunction With Undiagnosed Hypertension, Hypercholesterolemia, and Diabetes Among Men Aged $\geq 20$ Years in NHANES 2001-2004

\begin{tabular}{|c|c|c|c|c|}
\hline \multirow[b]{2}{*}{ Characteristic } & \multicolumn{2}{|c|}{$\begin{array}{l}\text { Undiagnosed Hypertension } \\
\qquad(n=2,224)\end{array}$} & \multicolumn{2}{|c|}{$\begin{array}{l}\text { Undiagnosed Hypercholesterolemia } \\
\qquad(n=2,287)\end{array}$} \\
\hline & $\begin{array}{l}\text { Unadjusted } \\
\text { OR }(95 \% \mathrm{Cl})\end{array}$ & $\begin{array}{c}\text { Adjusted } \\
\text { OR }(95 \% \mathrm{CI})\end{array}$ & $\begin{array}{l}\text { Unadjusted } \\
\text { OR }(95 \% \mathrm{Cl})\end{array}$ & $\begin{array}{l}\text { Adjusted } \\
\text { OR }(95 \% \mathrm{CI})\end{array}$ \\
\hline Erectile dysfunction & $2.35(1.78-3.11)$ & $1.27(0.87-1.85)$ & $0.73(0.47-1.15)$ & $0.67(0.42-1.07)$ \\
\hline \multicolumn{5}{|l|}{ Age-group, y } \\
\hline 20-39 (ref) & 1.00 & 1.00 & 1.00 & 1.00 \\
\hline $40-59$ & $2.47(1.69-3.61)$ & $2.38(1.55-3.66)^{\mathrm{a}}$ & $1.88(1.25-2.84)$ & $1.84(1.24-2.75)^{\mathrm{a}}$ \\
\hline$\geq 60$ & $7.29(4.90-10.84)$ & $7.41(4.43-12.37)^{\mathrm{a}}$ & $1.12(0.76-1.65)$ & $1.45(0.87-2.43)$ \\
\hline \multicolumn{5}{|l|}{ Ethnicity } \\
\hline Non-Hispanic white (ref) & 1.00 & 1.00 & 1.00 & 1.00 \\
\hline Non-Hispanic black & $1.47(1.07-2.02)$ & $1.99(1.34-2.97)^{\mathrm{a}}$ & $0.76(0.47-1.23)$ & $0.87(0.54-1.40)$ \\
\hline Mexican American & $0.64(0.41-0.98)$ & $0.90(0.60-1.35)$ & $0.92(0.64-1.31)$ & $0.97(0.65-1.46)$ \\
\hline Other & $0.66(0.34-1.30)$ & $0.92(0.46-1.85)$ & $1.13(0.64-1.99)$ & $1.37(0.77-2.44)$ \\
\hline Physically active & $0.99(0.77-1.28)$ & $0.84(0.62-1.13)$ & $0.82(0.59-1.14)$ & $0.84(0.60-1.18)$ \\
\hline \multicolumn{5}{|l|}{ Alcohol use } \\
\hline Never (ref) & 1.00 & 1.00 & 1.00 & 1.00 \\
\hline Former & $1.57(0.78-3.17)$ & $1.31(0.53-3.25)$ & $1.28(0.54-3.04)$ & $0.90(0.36-2.26)$ \\
\hline Current & $0.85(0.47-1.51)$ & $0.95(0.44-2.06)$ & $3.12(1.57-6.21)$ & $2.48(1.20-5.10)^{\mathrm{a}}$ \\
\hline Current smoker & $0.65(0.43-0.98)$ & $0.82(0.50-1.32)$ & $1.59(1.16-2.18)$ & $1.65(1.17-2.32)^{\mathrm{a}}$ \\
\hline History of hypertension & $n / a^{b}$ & $n / a^{b}$ & $1.10(0.72-1.68)$ & $0.95(0.56-1.61)$ \\
\hline History of high cholesterol & $1.21(0.87-1.68)$ & $0.71(0.48-1.05)$ & $n / a^{b}$ & $n / a^{b}$ \\
\hline History of diabetes & $0.96(0.46-1.98)$ & $0.56(0.28-1.14)$ & $0.54(0.27-1.08)$ & $0.45(0.21-0.97)^{\mathrm{a}}$ \\
\hline History of cardiovascular disease & $1.11(0.45-2.74)$ & $0.59(0.20-1.76)$ & $1.20(0.62-2.33)$ & $1.24(0.60-2.59)$ \\
\hline Family history of hypertension/stroke & $0.90(0.60-1.35)$ & $1.22(0.76-1.95)$ & $0.75(0.53-1.06)$ & $0.68(0.47-0.99)^{\mathrm{a}}$ \\
\hline Family history of angina/heart attack & $0.59(0.38-0.92)$ & $0.68(0.41-1.13)$ & $1.12(0.71-1.78)$ & $1.18(0.74-1.90)$ \\
\hline Family history of diabetes & $0.93(0.74-1.18)$ & $1.02(0.78-1.32)$ & $1.33(0.95-1.87)$ & $1.30(0.92-1.84)$ \\
\hline \multicolumn{5}{|l|}{ Weight status } \\
\hline Normal weight/underweight (ref) & 1.00 & 1.00 & 1.00 & 1.00 \\
\hline Overweight & $2.10(1.45-3.04)$ & $1.75(1.15-2.67)^{\mathrm{a}}$ & $2.23(1.51-3.30)$ & $2.17(1.46-3.23)^{a}$ \\
\hline Obese & $3.11(2.18-4.46)$ & $2.37(1.64-3.43)^{\mathrm{a}}$ & $2.79(1.70-4.58)$ & $2.74(1.68-4.47)^{\mathrm{a}}$ \\
\hline
\end{tabular}

tion further suggested that the relationship between erectile dysfunction and undiagnosed diabetes was strongest in the 40 to 59 age-group. For the average man between 40 and 59 years of age, the predicted probability of having undiagnosed diabetes increased from 1 in 50 (2.04\% of men) without erectile dysfunction to 1 in $10(10.4 \%)$ with erectile dysfunction.

\section{DISCUSSION}

Our results provide evidence of the importance of erectile dysfunction as a marker of undiagnosed diabetes, particularly in middle-aged men. They support previous studies suggesting that the prognostic value of erectile dysfunction for CVD is strongest in middleaged men younger than $60 .{ }^{5}$ Erectile dysfunction can act as an important tool to trigger both patients and physicians to screen for diabetes mellitus. Although we observed significant associations between undiagnosed diabetes and more traditional cardiovascular risk factors, erectile dysfunction is unique because of its common symptomatology and available treatment options. As such, it can act as a useful incentive for men to access the health care system and be readily screened.

A number of study limitations should be addressed. First, although the question on erectile dysfunction was asked in a private room through a computerassisted self-interview, because of the sensitive nature of the condition, it is possible that erectile dysfunction was underreported. This misclassification would have diluted the observed effect size. As a result, the estimates reported may in fact underestimate the association between erectile dysfunction and undiagnosed cardiometabolic risk factors. Second, increased recognition of the relationship between erectile dysfunction and cardiovascular disease may have altered screening 
Undiagnosed Diabetes

$(\mathrm{n}=1,417)$

\begin{tabular}{|c|c|}
\hline $\begin{array}{l}\text { Unadjusted } \\
\text { OR }(95 \% \mathrm{Cl}) \\
\end{array}$ & $\begin{array}{c}\text { Adjusted } \\
\text { OR (95\% CI) }\end{array}$ \\
\hline $4.58(2.54-8.24)$ & $2.20(1.10-4.37)^{a}$ \\
\hline 1.00 & 1.00 \\
\hline $8.24(2.49-27.19)$ & $5.56(1.78-17.35)^{a}$ \\
\hline $14.83(5.19-42.34)$ & $8.70(2.91-26.03)^{\mathrm{a}}$ \\
\hline 1.00 & 1.00 \\
\hline $0.78(0.39-1.56)$ & $1.25(0.57-2.71)$ \\
\hline $0.25(0.11-0.58)$ & $0.53(0.21-1.33)$ \\
\hline $1.21(0.46-3.15)$ & $2.39(0.87-6.55)$ \\
\hline $0.70(0.33-1.47)$ & $0.73(0.35-1.55)$ \\
\hline 1.00 & 1.00 \\
\hline $1.73(0.56-5.36)$ & $1.42(0.47-4.30)$ \\
\hline $0.62(0.23-1.68)$ & $0.67(0.29-1.55)$ \\
\hline $0.57(0.25-1.34)$ & $1.00(0.41-2.41)$ \\
\hline $3.88(2.16-6.96)$ & $1.83(0.92-3.65)$ \\
\hline $2.89(1.68-4.98)$ & $1.55(0.81-2.99)$ \\
\hline $\mathrm{n} / \mathrm{a}^{\mathrm{b}}$ & $n / a^{b}$ \\
\hline $1.48(0.71-3.07)$ & $0.46(0.18-1.17)$ \\
\hline $0.93(0.54-1.62)$ & $0.96(0.54-1.72)$ \\
\hline $1.36(0.65-2.86)$ & $1.26(0.50-3.14)$ \\
\hline $2.24(1.40-3.59)$ & $2.35(1.50-3.68)^{\mathrm{a}}$ \\
\hline 1.00 & 1.00 \\
\hline $2.83(0.74-10.81)$ & 2.28 (0.74-6.99) \\
\hline $5.98(1.69-21.10)$ & $3.60(1.30-9.93)^{\mathrm{a}}$ \\
\hline
\end{tabular}

practices of physicians. As such, the prevalence of undiagnosed cardiometabolic risk factors may in fact be lower now. Finally, as this study was cross-sectional, it was not possible to determine the temporal relationship between erectile dysfunction and the undiagnosed risk factors. This shortcoming does not, however, affect the importance of erectile dysfunction as a marker of undiagnosed cardiovascular risk factors for early intervention.

In conclusion, men with erectile dysfunction, particularly those who are middle-aged, should be made aware of their potential for having underlying diabetes and be encouraged to obtain screening. In the same vein, physicians should be vigilant in obtaining sexual histories in middle-aged men and screening those with erectile dysfunction for diabetes.
To read or post commentaries in response to this article, see it online at http://www.annfammed.org/content/13/4/331.

Key words: reproductive system, sexual function; health promotion; disease prevention; cardiovascular disease; special population, men; risk factors; screening

Submitted December 7, 2014; submitted, revised, May 19, 2015; accepted May 27, 2015.

Funding support: Sean Skeldon is supported in part by the CIHR and the Western Regional Training Centre (WRTC) for Health Services Research. Larry Goldenberg is supported by the Stephen Jarislowski Chair in Urologic Sciences at Vancouver General Hospital. Michael Law received salary support through a New Investigator Award from the Canadian Institutes of Health Research and a Scholar Award from the Michael Smith Foundation for Health Research. Michael Law reports grants from Canadian Institutes for Health Research during the conduct of the study. Michael Law received personal fees from Health Canada, outside the submitted work. Allan Detsky has no financial supports or conflicts of interest to report.

Supplementary materials: Available at http://www.AnnFamMed. org/content/13/4/331/suppl/DC1/

\section{References}

1. Go AS, Mozaffarian D, Roger VL, et al; American Heart Association Statistics Committee and Stroke Statistics Subcommittee. Heart disease and stroke statistics-2013 update: a report from the American Heart Association. Circulation. 2013;127(1):e6-e245.

2. Fryar CD, Hirsch R, Eberhardt MS, Yoon SS, Wright JD. Hypertension, high serum total cholesterol, and diabetes: racial and ethnic prevalence differences in U.S. adults, 1999-2006. NCHS Data Brief. 2010;(36):1-8.

3. Towfighi A, Zheng L, Ovbiagele B. Sex-specific trends in midlife coronary heart disease risk and prevalence. Arch Intern Med. 2009; 169(19):1762-1766.

4. Sandman D, Simantov E, An C, Fund C, Harris L. Out of Touch: American Men and the Health Care System. New York, NY: Commonwealth Fund; 2000.

5. Inman BA, Sauver JL, Jacobson DJ, et al. A population-based, longitudinal study of erectile dysfunction and future coronary artery disease. Mayo Clin Proc. 2009;84(2):108-113.

6. Curtin LR, Mohadjer LK, Dohrmann SM, et al. The National Health and Nutrition Examination Survey: sample design, 1999-2006. Vital Health Stat 2. 2012;(155):1-39.

7. O'Donnell AB, Araujo AB, Goldstein I, McKinlay JB. The validity of a single-question self-report of erectile dysfunction. Results from the Massachusetts Male Aging Study. J Gen Intern Med. 2005;20(6): 515-519.

8. Selvin E, Burnett AL, Platz EA. Prevalence and risk factors for erectile dysfunction in the US. Am J Med. 2007;120(2):151-157.

9. Bang H, Edwards AM, Bomback AS, et al. Development and validation of a patient self-assessment score for diabetes risk. Ann Intern Med. 2009;151(11):775-783.

10. Johnson C, Paulose-Ram R, Ogden C, et al. National Health and Nutrition Examination Survey: analytic guidelines, 1999-2010. National Center for Health Statistics. Vital Health Stat 2. 2013;(161):1-24.

11. Lohr SL. Sampling: Design and Analysis. Pacific Grove, CA: Duxbury Press; 1999. 